\title{
The role of watershed characteristics, permafrost thaw, and wildfire on dissolved organic carbon biodegradability and water chemistry in Arctic headwater streams
}

\author{
J. R. Larouche ${ }^{1}$, B. W. Abbott ${ }^{2,3}$, W. B. Bowden ${ }^{4}$, and J. B. Jones ${ }^{5}$ \\ ${ }^{1}$ The Rubenstein School of Environment and Natural Resources, University of Vermont, Burlington, Vermont, USA \\ ${ }^{2}$ Institute of Arctic Biology and Department of Biology \& Wildlife, University of Alaska Fairbanks, Fairbanks, Alaska, USA \\ ${ }^{3}$ Université de Rennes 1, OSUR, CNRS, UMR6553 ECOBIO, Rennes, France \\ ${ }^{4}$ The Rubenstein School of Environment and Natural Resources, University of Vermont, Burlington, Vermont, USA \\ ${ }^{5}$ Institute of Arctic Biology and Department of Biology \& Wildlife, University of Alaska Fairbanks, Fairbanks, Alaska, USA
}

Correspondence to: J. R. Larouche (julia.larouche@gmail.com)

Received: 24 January 2015 - Published in Biogeosciences Discuss.: 04 March 2015

Accepted: 28 June 2015 - Published: 20 July 2015

\begin{abstract}
In the Alaskan Arctic, rapid climate change is increasing the frequency of disturbance including wildfire and permafrost collapse. These pulse disturbances may influence the delivery of dissolved organic carbon (DOC) to aquatic ecosystems, however the magnitude of these effects compared to the natural background variability of DOC at the watershed scale is not well known. We measured DOC quantity, composition, and biodegradability from 14 river and stream reaches (watershed sizes ranging from $1.5-167 \mathrm{~km}^{2}$ ) some of which were impacted by permafrost collapse (thermokarst) and fire. We found that region had a significant impact on quantity and biodegradability of DOC, likely driven by landscape and watershed characteristics such as lithology, soil and vegetation type, elevation, and glacial age. However, contrary to our hypothesis, we found that streams disturbed by thermokarst and fire did not contain significantly altered labile DOC fractions compared to adjacent reference waters, potentially due to rapid ecosystem recovery after fire and thermokarst as well as the limited spatial extent of thermokarst. Overall, biodegradable DOC ranged from 4 to $46 \%$ and contrary to patterns of DOC biodegradability in large Arctic rivers, seasonal variation in DOC biodegradability showed no clear pattern between sites, potentially related to stream geomorphology and position along the river network. While thermokarst and fire can alter DOC quantity and biodegradability at the scale of the feature, we conclude that tundra ecosystems are resilient to these types of disturbance.
\end{abstract}

\section{Introduction}

As the Arctic warms, the biogeochemical signature of its rivers and streams will likely be an indicator of the response of aquatic and adjacent terrestrial ecosystems to climate change (Holmes et al., 2000; McClelland et al., 2007; Frey and McClelland, 2009). Arctic freshwater ecosystems process and transport substantial loads of dissolved organic carbon (DOC) delivering 34-38 $\mathrm{Tg} \mathrm{yr}^{-1}$ to the Arctic Ocean, and mineralizing or immobilizing another $37-84 \mathrm{Tg} \mathrm{yr}^{-1}$ (McGuire et al., 2009; Holmes et al., 2012). Biodegradable DOC (BDOC) is the biologically available fraction of DOC and is defined as the percent DOC loss over time (typically 7 to 40 days) due to mineralization or uptake (McDowell et al., 2006). Given anticipated changes in the arctic climate, there has been growing interest to quantify changes in the magnitude of overall DOC flux (Holmes et al., 2012; Tank et al., 2012) as well as the BDOC exported by small headwater streams and large rivers in the Arctic (Striegl et al., 2005; Spencer et al., 2008; O’Donnell et al., 2012), particularly in areas impacted by disturbances associated with climate change.

Disturbance in arctic and boreal ecosystems is expected to escalate in response to future changes in climate. Examples of physical responses to climate change in northern Alaska include the deepening of the seasonally thawed surface soil or active layer (Shiklomanov et al., 2010), permafrost warming (Romanovsky et al., 2002, 2011), permafrost collapse 
(Jorgenson et al., 2006; Belshe et al., 2013; Balser et al., 2014), and wildfire (Randerson et al., 2006). There is evidence of recent increases in permafrost disturbance (Gooseff et al., 2009; Balser et al., 2014) on the North Slope of Alaska and wildfire has the potential to become a major disturbance factor in the tundra region (Higuera et al., 2011; Rocha et al., 2012).

Thaw of ice-rich permafrost results in soil collapse or subsidence, termed thermokarst (Kokelj and Jorgenson, 2013). Thermokarst can export substantial quantities of sediment, carbon, nitrogen, and phosphorus to Arctic streams, rivers and lakes (Kokelj et al., 2005, 2009, 2013; Bowden et al., 2008; Lamoureux and Lafrenière, 2009; Lewis et al., 2011; Dugan et al., 2012; Malone et al., 2013; Harms et al., 2014). The magnitude of exported material depends largely on thermokarst size, type, activity, and hydrologic connectivity (Lewis et al., 2011; Lafrenière and Lamoureux, 2013; Abbott et al., 2014). For example, thermokarst features can mobilize substantial amounts of sediments and nutrients that are not delivered to downslope aquatic ecosystems and instead retained along the hillslopes or in the riparian zone (Larouche, 2015). DOC in the outflow of thermokarst features is highly labile (Woods et al., 2011; Vonk et al., 2013; Abbott et al., 2014), particularly when exposed to light (Cory et al., 2013). While sediment and solute concentrations and the proportion of BDOC can be high in thermokarst outflow, the impact on the watershed depends on the total mass flux or load (Lewis et al., 2012). The effects of thermokarst disturbance on Arctic aquatic ecosystems are poorly understood at the watershed scale, limiting useful inferences about future system response to climate change.

The organic horizon of tundra soils insulates permafrost from warm summer air temperatures. The removal of surface soil carbon during fire promotes underlying permafrost degradation (Burn, 1998; Yoshikawa et al., 2002), increases thaw depth for decades post-fire (Rocha et al., 2012), and triggers thermokarst development (Osterkamp and Romanovsky, 1999). Wildfire disturbance in lower latitude ecosystems can increase concentrations of major ions and nutrients in soil and stream water (Bayley et al., 1992a, b; Chorover et al., 1994). In the boreal forest of Alaska, stream DOC concentration declined following a wildfire, presumably due to loss of microbial biomass (Schindler et al., 1997; Petrone et al., 2007; Betts and Jones, 2009) and bioavailable dissolved organic matter in streams decreased post-fire and during thermokarst formation (Balcarczyk et al., 2009).

Across various biomes the composition and biodegradability of riverine DOC changes seasonally due to a tight coupling between terrestrial and aquatic ecosystems (Holmes et al., 2008; Fellman et al., 2009; Wang et al., 2012). In the Arctic, DOC concentration and biodegradability is highest during snowmelt and early spring and decreases progressively through the summer (Holmes et al., 2008; Mann et al., 2012; Vonk et al., 2013). However, the majority of studies investigating Arctic BDOC have focused on downstream reaches in large alluvial systems leaving the seasonal and spatial variation of BDOC in headwater streams largely unknown.

The questions we address in this paper are, "Does BDOC and water chemistry differ at the watershed scale among landscape types?" and "Does BDOC and water chemistry differ in streams impacted by thermokarst and fire?" To answer these questions we measured the quantity, biodegradability, and aromaticity of DOC and background water chemistry from Arctic headwater streams and rivers. We sampled watersheds in three geographic regions affected by a combination of fire and thermokarst to evaluate controls on DOC quantity and biodegradability at the watershed scale. We hypothesized thermokarst would increase DOC concentrations and BDOC due to the delivery of labile carbon from thawed permafrost. Because wildfire in the Arctic can directly impact DOC export, as well as have secondary effects due to changes in active layer depth and extent of permafrost, we hypothesized that wildfire may decrease BDOC due to the combustion of soil carbon stocks during fire. However, if wildfire promotes extensive permafrost degradation and thermokarst production then BDOC concentrations might increase.

\section{Methods}

\subsection{Study areas and sampling design}

We took advantage of natural disturbance to test our hypotheses. We collected stream water from 16 reaches, 11 of which were individual Arctic rivers and streams on or near the North Slope of Alaska including the regions around the Toolik Field Station, Feniak Lake, and the Anaktuvuk River wildfire area (Fig. 1, Table 1). Seven of the stream sites were apparently undisturbed (reference) reaches and nine sites were impacted by a combination of wild fire and thermokarst of various types, including retrogressive thaw slumps and active layer detachment slides, two of the most common thermokarst morphologies in upland landscapes (Kokelj and Jorgenson, 2013). The Toolik Field Station is located $254 \mathrm{~km}$ north of the Arctic Circle and $180 \mathrm{~km}$ south of the Arctic Ocean. The average annual temperature is $-10^{\circ} \mathrm{C}$ and average monthly temperatures range from $-25^{\circ} \mathrm{C}$ in January to $11.5^{\circ} \mathrm{C}$ in July. The Toolik area receives $320 \mathrm{~mm}$ of precipitation annually with $200 \mathrm{~mm}$ falling between June and August (Toolik Environmental Data Center Team, 2011). Feniak Lake is located $360 \mathrm{~km}$ west of the Toolik Field Station in the central Brooks Range in the Noatak National Preserve. The average annual temperature approximately $25 \mathrm{~km}$ southwest of Feniak Lake is $-8.1^{\circ} \mathrm{C}$ and the Feniak region receives more precipitation than Toolik and Anaktuvuk with an annual average of $408 \mathrm{~mm}$ (WRCC, 2011). The Anaktuvuk area receives the bulk of its precipitation during the months of June through September with a long-term summer average of $107 \mathrm{~mm}$ (Jones et al., 2009). All three areas are un- 
derlain by continuous permafrost. Landscapes in the Toolik and Feniak Lake area are underlain by glacial till, bedrock and loess parent materials ranging in age from 10-400 ka (Hamilton, 2003). The two sites sampled in the Toolik area consist primarily of glacial deposits assigned to the Sagavanirktok River (middle Pleistocene) and Itkillik I and II (late Pleistocene) glaciations of the central Brooks Range (Hamilton, 2003). Upland substrates in the Feniak area include noncarbonate, carbonate and ultramafic lithologies (Jorgenson et al., 2002), and are typically overlain by colluvial deposits, soliflucted hillslopes, glacial till and outwash primarily of early Itkillik age (roughly 50000 years BP; Hamilton, 2009). The Anaktuvuk River area is on a substantially older (>700 ka) landscape farther north from the field station and foothills. The southern one-third portion of the burned area rests on a combination of upland colluvium or old glacial surfaces while the northern two-thirds of the burn surface rests on eolian silt deposited in the mid-Pleistocene (Jorgenson et al., 2010).

In the summer of 2007 in the Anaktuvuk River area, above-normal temperatures, below-normal precipitation, and extremely low soil moisture conditions favored fire conditions when a lightning strike ignited the tundra on 16 July. Air temperature in July to September of that year was the warmest over a 129 -year record, with a $+2.0^{\circ} \mathrm{C}$ anomaly, and that summer was the driest of a 29-year record with the 4 month total precipitation just over $20 \mathrm{~mm}$ (Jones et al., 2009). The resulting fire was the largest fire on record for the North Slope of Alaska, burning $1039 \mathrm{~km}^{2}$ and removing $\sim 31 \%$ of tundra ecosystem carbon (Mack et al., 2011).

\subsection{Sample collection}

In 2011, we sampled reference streams and streams impacted by thermokarst and wildfire near the Toolik Field Station, the Anaktuvuk burn scar, and Feniak Lake. In the Toolik area we sampled the Kuparuk River (Site 1) and Oksrukyuik Creek (Site 2), both of which have not been impacted by fire or thermokarst. In the Anaktuvuk area, we sampled four reference rivers on 6 August 2011, two of which we analyzed for BDOC (Burn Reference $1=$ Site 3 and Burn Reference $2=$ Site 4 ), located to the east of the burn boundary to serve as landscape references for the sites located within the burned scar. Within the Anaktuvuk burned boundary we sampled four unique streams including the South (Site 5) and North (Site 6) Rivers, both of which were burned, but undisturbed by thermokarst. Also within the Anaktuvuk scar, we sampled two watersheds referred to as the Valley of Thermokarst; one watershed (Sites 7a and 7b) that was burned but had no thermokarst features present and one watershed (Sites $8 \mathrm{a}$ and $8 b)$ was burned and contained numerous active layer detachment slides that formed on the south-facing slope post-fire. In the Feniak area we focused our efforts at two sites. We sampled a small watershed containing two tributaries, Bloodslide Reference (Site 9) that drained the northwestern por- tion of the watershed unimpacted by thermokarst and Bloodslide Impacted (Site 10) that drained the southeastern side of the watershed and received the outflow of a very recent, active layer detachment slide. The other location in Feniak was along a larger headwater system impacted by three large, active thaw slumps and we sampled upstream and downstream of both the first (Sites 11a and 11b) and third (Sites 12a and 12b) thaw slump features.

To quantify seasonal variability of BDOC we took repeat measurements 4-5 times over the 2011 summer season from the Toolik and Anaktuvuk stream sites, except for the two Anaktuvuk reference sites that were sampled once (Sites 3 and 4). Due to their remote locations, sites located in the Feniak Lake area were sampled once during 2011. At each stream site, we collected four replicate field samples, which we filtered $(0.7 \mu \mathrm{m}$, Advantec GF-75) into $250 \mathrm{~mL}$ amber LDPE bottles for transport to Toolik Field Station or Feniak Lake base camp and set up incubations within $24 \mathrm{~h}$ of collection. We also collected separate bottles for background water chemistry (filtered and preserved for later analyses) and for photometric absorbance analyses (filtered and measured within $24 \mathrm{~h}$, except for the Feniak samples which were measured within a week back at the Toolik Field Station).

\subsection{BDOC incubation assays}

We followed the BDOC incubation protocol described in Abbott et al. (2014). In brief, we amended all samples with nutrients (increasing ambient concentrations by $80 \mu \mathrm{M}$ $\mathrm{NH}_{4}^{+} / \mathrm{NO}_{3}^{-}$and $10 \mu \mathrm{MPO}_{4}^{3-}$ ), inoculated them with a common bacterial community from the local site, stored samples in the dark at room temperature, and measured DOC loss at three time steps: initial DOC at day $0\left(t_{0}\right)$, at day $10\left(t_{10}\right)$, and at the end of a 40-day incubation period $\left(t_{40}\right)$. We found that the day 10 incubations yielded inconsistent results (i.e. DOC gain at $t_{10}$ yielding negative BDOC) and so for the purposes of this paper we focus only on DOC loss over 40 days $\left(t_{40}\right)$. DOC loss (absolute loss and percentage loss relative to initial concentration) was calculated for each field replicate sample $(n=4)$ on each sampling date. Mean values for initial DOC concentration $(\mu \mathrm{m})$; absolute 40-day loss $(\mu \mathrm{m})$; and 40-day percent loss $(\%)$ were calculated from the 4 field replicates for each site and date. Quality control consisted of carefully inspecting each of the DOC concentrations from each of the four replicates, for each time stamp, for each sample. Samples for which 1 of 4 incubation replicates were considerably different than the others which were flagged and further inspected. If the questionable value was more than two standard deviations from the mean then it was removed. Only one replicate out of the total of 184 samples was removed.

\subsection{DOC composition $\left(\mathrm{SUVA}_{254}\right)$}

We characterized DOC composition by specific ultraviolet absorbance at $254 \mathrm{~nm}\left(\mathrm{SUVA}_{254} ; \mathrm{L} \mathrm{mg} \mathrm{C}^{-1} \mathrm{~m}^{-1}\right)$, a photo- 
Table 1. Watershed characteristics of sampling sites.

\begin{tabular}{|c|c|c|c|c|c|c|c|c|c|}
\hline Region & $\begin{array}{r}\text { Site } \\
\text { ID }\end{array}$ & $\begin{array}{l}\text { Site } \\
\text { Name }\end{array}$ & $\begin{array}{l}\text { Stream } \\
\text { Type }\end{array}$ & $\begin{array}{r}\text { Stream Order }{ }^{1} \\
(\text { Strahler })\end{array}$ & $\begin{array}{l}\text { Watershed } \\
\text { Area }^{1}\left(\mathrm{~km}^{2}\right)\end{array}$ & $\begin{array}{r}\text { Watershed } \\
\text { Elevation }^{1}(\mathrm{~m})\end{array}$ & $\begin{array}{r}\text { Watershed } \\
\text { Slope }^{1} \text { (degrees) }\end{array}$ & $\begin{array}{r}\text { Channel } \\
\text { Length }^{1}(\mathrm{~km})\end{array}$ & $\begin{array}{r}\text { Bedrock }^{2} \\
(\%)\end{array}$ \\
\hline Toolik & 1 & Kuparuk River & Alluvial & 4 & 132.8 & 987 & 8.9 & 239 & 3.0 \\
\hline Toolik & 2 & Oksrukyuik Creek & Alluvial & 3 & 57.2 & 868 & 5.2 & 104 & 0.0 \\
\hline Anaktuvuk & 3 & Burn Reference Site 1 & Alluvial & 3 & 52.6 & 213 & 4.9 & 128 & 0.0 \\
\hline Anaktuvuk & 4 & Burn Reference Site 2 & Alluvial & 4 & 167.3 & 353 & 5 & 341 & 0.0 \\
\hline Anaktuvuk & 5 & South River & Alluvial & 4 & 96.5 & 415 & 4.7 & 170 & 0.0 \\
\hline Anaktuvuk & 6 & North River & Beaded & 4 & 72.5 & 351 & 5 & 96 & 0.0 \\
\hline Anaktuvuk & 7 & Valley of Thermokarst Reference & Beaded & 3 & 15.7 & 373 & 5.7 & 23 & 0.0 \\
\hline Anaktuvuk & 8 & Valley of Thermokarst Impacted & Beaded & 3 & 26.7 & 391 & 5.1 & 41 & 0.0 \\
\hline Feniak & 9 & Bloodslide Reference & Alluvial & 2 & 1.5 & 750 & - & - & - \\
\hline Feniak & 10 & Bloodslide Impacted & Alluvial & 2 & 5.2 & 750 & 12.1 & 4 & 100 \\
\hline Feniak & 11 & Twin 1 & Alluvial & 2 & 23.2 & 700 & 9.8 & 16 & 20.9 \\
\hline Feniak & 12 & Twin 3 & Alluvial & 3 & 43 & 826 & 14.8 & 31 & 11.3 \\
\hline
\end{tabular}

Table 1. Continued.

\begin{tabular}{|c|c|c|c|c|c|c|}
\hline $\begin{array}{l}\text { Variable Ground } \\
\operatorname{Ice}^{2}(\%)\end{array}$ & $\begin{array}{r}\text { Glacial } \\
\operatorname{Age}^{3}(\mathrm{ka})\end{array}$ & Ecotype $^{4}$ & $\begin{array}{r}\text { Vegetation } \\
\text { Code }^{5}\end{array}$ & Vegetation $^{5}$ & $\begin{array}{l}\text { Disturbance } \\
\text { Type }\end{array}$ & $\begin{array}{r}\text { Coordinates } \\
\text { (UTM) }\end{array}$ \\
\hline 97.0 & $200-700$ & Lowland Birch-Ericaceous Low Shrub & II.C.2.a. & Open Low Mixed Shrub-Sedge Tussock Tundra & Reference & $68.6430-149.4028$ \\
\hline 91.0 & $200-700$ & Lowland Sedge-Willow Fen & II.C.2.h. & Open Low Willow-Sedge Shrub Tundra & Reference & $68.6709-149.1380$ \\
\hline 0.0 & $>700$ & Lowland Willow Low Shrub & II.C.1.b. & Closed Low Willow Shrub & Reference & $69.2889-150.4327$ \\
\hline 0.0 & $>700$ & Riverine Moist Willow Tall Shrub & II.B.1.a. & Closed Tall Willow Shrub & Reference & $69.1764-150.1558$ \\
\hline 45.7 & $>700$ & Lowland Willow Low Shrub & II.C.1.b. & Closed Low Willow Shrub & Burned & $68.9973-150.3080$ \\
\hline 3.6 & $>700$ & Lowland Willow Low Shrub & II.C.1.b. & Closed Low Willow Shrub & Burned & $69.0536-150.4003$ \\
\hline 0.0 & $>700$ & Upland Willow Low Shrub & II.C.2.h. & Open Low Willow-Sedge Shrub Tundra & Burned & $68.9350-150.6861$ \\
\hline 0.0 & $>700$ & Upland Dwarf Birch-Tussock Shrub & II.C.2.a. & Open Low Mixed Shrub-Sedge Tussock Tundra & Burned + ALDs & $68.9611-150.7008$ \\
\hline- & $200-700$ & Alpine Wet Sedge Meadow & II.A.3.c. & Wet Sedge Herb Meadow Tundra & Reference & $68.2794-157.0256$ \\
\hline 0.0 & $200-700$ & Alpine Wet Sedge Meadow & II.A.3.c. & Wet Sedge Herb Meadow Tundra & ALD & $68.2809-157.0245$ \\
\hline 0.0 & $50-80$ & Upland Sedge-Dryas Meadow & III.A.2.j. & Sedge-Dryas Tundra & Reference \& TS & $67.9620-156.7814$ \\
\hline 0.0 & $50-80$ & Upland Sedge-Dryas Meadow & III.A.2.j. & Sedge-Dryas Tundra & Reference \& TS & $67.9612-156.8304$ \\
\hline
\end{tabular}

${ }^{1}$ Nolan (2003) ; ${ }^{2}$ Jorgenson et al. (2008); ${ }^{3}$ Hamilton and Labay (2011); ${ }^{4}$ Jorgenson et al. (2010); ${ }^{5}$ Viereck et al. (1992).

metric measure of DOC aromaticity (Weishaar et al., 2003). UV absorbance was measured on a Shimadzu UV-1601 using a $1.0 \mathrm{~cm}$ quartz cell and the baseline was corrected using dionized water at the beginning of each sample run to ensure that there was no absorbance measured. $\mathrm{SUVA}_{254}$ values were calculated by dividing UV absorbance by DOC concentration in $\mathrm{mg} \mathrm{L}^{-1}$.

\subsection{Water chemistry}

We analyzed water samples for total suspended sediment (TSS, $\mathrm{mg} \mathrm{L}^{-1}$ ); alkalinity $\left(\mu \mathrm{eq} \mathrm{L}^{-1}\right)$; total dissolved nitrogen (TDN, $\mu \mathrm{M})$; ammonium $\left(\mathrm{NH}_{4}^{+}, \mu \mathrm{M}\right)$; nitrate $\left(\mathrm{NO}_{3}^{-}, \mu \mathrm{M}\right)$; total dissolved phosphorus (TDP, $\mu \mathrm{M}$ ); soluble reactive phosphorus as phosphate $\left(\mathrm{PO}_{4}^{3-}, \mu \mathrm{M}\right)$; and cations (magnesium, $\mathrm{Mg}^{+}$; calcium, $\mathrm{Ca}^{+}$; potassium, $\mathrm{K}^{+}$; sodium, $\mathrm{Na}^{+}, \mathrm{mg} \mathrm{L}^{-1}$ ). Table S1 in the Supplement summarizes the methods and instruments used for water chemistry analyses. The sites in the Anaktuvuk and Toolik areas were sampled with ISCO automated samplers deployed for daily composite sampling (except for Sites $7 \mathrm{~b}$ and $8 \mathrm{~b}$ which were sampled manually). Sites in the Feniak area were sampled manually.

\subsection{Statistics}

The variance values around all mean values reported below are standard errors (SE). We tested for differences in BDOC metrics and background water chemistry variables among streams within groups defined a priori by analysis of variance (ANOVA). Significant differences between streams $(p<0.05)$ were further evaluated using Tukey's multiplecomparison test (Lane, 2010). We considered comparisons with a $p$ value $<0.1$ to be marginally significant. For all analyses, we evaluated normality with normal probability plots and equal variance with Levene's test (Levene, 1960). In general, the majority of the data were consistently normally distributed. In the rare case that the Levene unequal variances test was significant, Welch's test (Welch, 1951) was used to detect differences instead of ANOVA. Normality plots, equal variance tests and ANOVA analyses were performed with JMP Pro version 11.0 (SAS Institute Inc. 2012). Linear regression was used to determine correlations between SUVA and BDOC \%, and also to determine relationships between BDOC \% and date for those sites that were measured repeatedly. Linear regression analyses were performed with SigmaPlot version 11.0 (Systat Software, Inc., San Jose California USA). 


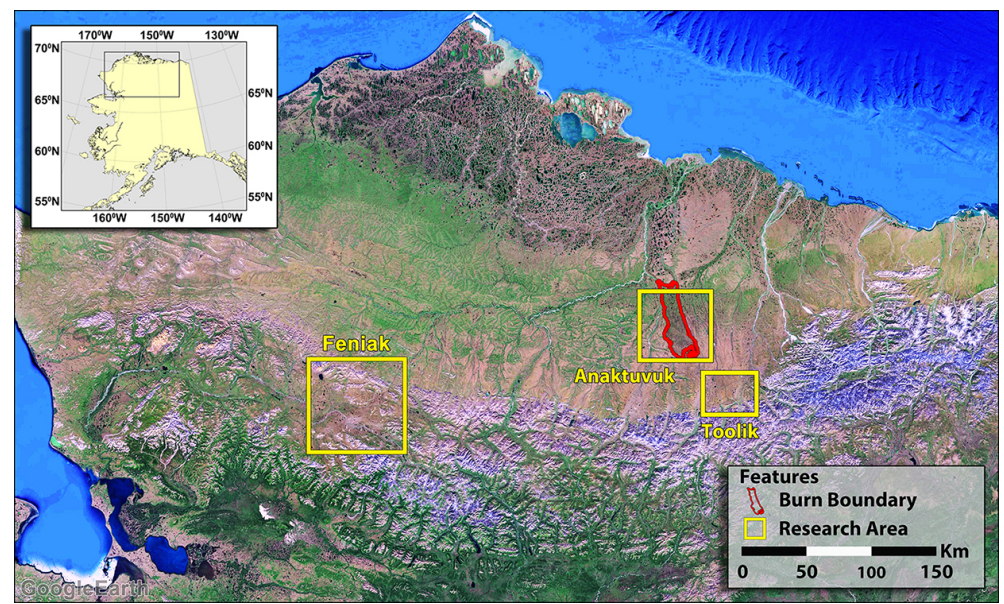

Figure 1. Map of study areas. Map credit: J. Noguera and R. Fulweber, Toolik Field Station GIS and Remote Sensing Facility.

\section{Results}

\subsection{Initial $\left(t_{0}\right)$ DOC concentrations}

Anaktuvuk reference sites had higher initial DOC concentrations $(977 \pm 103 \mu \mathrm{M}, n=2)$ than Feniak $(316 \pm 83.9 \mu \mathrm{M}$, $n=3, \quad P<0.001)$ and Toolik $(259 \pm 46.0 \mu \mathrm{M}, \quad n=10$, $P<0.0001)$ reference sites (Fig. S1a in the Supplement). The comparison of the reference and thermokarst-impacted sites in Feniak revealed no significant effect on initial DOC $(P=0.96$; Fig. 2a, left). Moreover, we found no influence of thermokarst on initial DOC $(P=0.92)$ by comparing the adjacent Reference and Impacted Valley of Thermokarst watersheds [Sites 7a and 7b and $8 \mathrm{~b}$ (burned) vs. 8a (burned + thermokarst)] (Fig. 2a, right). Combining all sites in a region together, the initial DOC concentration in the Anaktuvuk region $(1098 \pm 38.4 \mu \mathrm{M}, n=30)$ was more than three times greater than in the Feniak region $(312 \pm 85.5 \mu \mathrm{M}, n=6$, $P<0.0001)$ and in the Toolik region $(259 \pm 66.4 \mu \mathrm{M}, n=10$, $P<0.0001$ ) streams (Fig. 3a).

\subsection{BDOC}

The absolute BDOC concentrations in Reference Feniak streams $(125.2 \pm 17.0 \mu \mathrm{M}, n=3, P<0.01)$ and reference Anaktuvuk streams $(125.0 \pm 20.8 \mu \mathrm{M}, n=2, P<0.05)$ were greater than Toolik reference sites $(45.5 \pm 9.3 \mu \mathrm{M}, n=10$; Fig. S1b). Mean values for site specific BDOC metrics can be found in Table S2. Feniak reference sites contained the highest $\mathrm{BDOC} \%(38.1 \pm 2.6 \%, n=3)$ compared to Toolik $(18.5 \pm 1.4 \%, n=10, P<0.0001)$ and Anaktuvuk $(14.5 \pm 3.2 \%, n=30, P<0.001)$ reference sites (Fig. S1c). There was no significant effect of thermokarst inflow on absolute BDOC $(P=0.91)$ or BDOC \% $(P=0.99$; Fig. $2 \mathrm{~b}-$ c, left). Nor did we find an effect of thermokarst on absolute BDOC $(P=0.83)$ or BDOC $\%(P=0.71)$ in the Valley of Thermokarst [Sites $7 \mathrm{a}$ and $7 \mathrm{~b}$ and $8 \mathrm{~b}$ (burned) vs. 8a (burned + thermokarst)] (Fig. 2b-c, right). Combining all sites within a region, we found that the absolute BDOC (Fig. 3b) was significantly lower in the Toolik region $(45 \pm 15.1 \mu \mathrm{M}, n=10)$ compared to the Feniak region $(123 \pm 19.5 \mu \mathrm{M}, n=6, P<0.01)$ and the Anaktuvuk region $(105 \pm 8.7 \mu \mathrm{M}, n=30, P<0.01)$ streams. BDOC \% (Fig. 3c) was significantly different $(P<0.0001)$ among streams from all three regions: Feniak $(38.1 \pm 1.8 \%, n=6)$; Toolik (18.5 $\pm 1.4 \%, n=10)$; and Anaktuvuk $(9.6 \pm 0.8 \%$, $n=2)$.

\section{3 $\quad$ SUVA254 $_{2}$}

The values of $\mathrm{SUVA}_{254}$ ranged from 1.31 to $6.87 \mathrm{~L} \mathrm{mg} \mathrm{C}^{-1} \mathrm{~m}^{-1}$ across all streams sampled. The SUVA $_{254}$ values for the Anaktuvuk reference sites $\left(4.2 \pm 1.7 \mathrm{~L} \mathrm{mg} \mathrm{C}^{-1} \mathrm{~m}^{-1}, \quad n=2\right) \quad$ were significantly higher than the values from the Feniak reference sites $\left(1.8 \pm 0.4 \mathrm{~L} \mathrm{mg} \mathrm{C}^{-1} \mathrm{~m}^{-1}, n=3, P=0.01\right)$ or the Toolik reference sites $\left(2.1 \pm 0.1 \mathrm{~L} \mathrm{mg} \mathrm{C}^{-1} \mathrm{~m}^{-1}, n=10, P=0.01\right)$ reference sites (Fig. S1d). Thermokarst inflow had no significant impact on SUVA $_{254}$ in the Feniak sites $(P=0.79$, Fig. 2d, left). We also found no influence of thermokarst on $\operatorname{SUVA}_{254}(P=0.66)$ within the Valley of Thermokarst burned watersheds [Sites $7 \mathrm{a}$ and $7 \mathrm{~b}$ and $8 \mathrm{~b}$ (burned) vs. $8 \mathrm{a}$ (burned + thermokarst)] (Fig. 4d, right). Combining all sites within a region, the $\mathrm{SUVA}_{254}$ measurements differed significantly by region $(P<0.0001)$. Toolik and Feniak area streams had lower $\mathrm{SUVA}_{254}$ values (range 1.31-2.62 $\mathrm{L} \mathrm{mg} \mathrm{C}^{-1} \mathrm{~m}^{-1}$ ), indicative of low humic content and aromaticity, compared to streams in the Anaktuvuk area (range $2.57-6.87 \mathrm{~L} \mathrm{mg} \mathrm{C}^{-1} \mathrm{~m}^{-1}$ ). $\mathrm{SUVA}_{254}$ values from Anaktuvuk sites $\left(4.8 \pm 0.12 \mathrm{~L} \mathrm{mg} \mathrm{C}^{-1} \mathrm{~m}^{-1}, n=30\right)$ were more than double those in Feniak $\left(1.9 \pm 0.29 \mathrm{~L} \mathrm{mg} \mathrm{C}^{-1} \mathrm{~m}^{-1}\right.$, $n=6, P<0.0001)$ and Toolik $\left(2.1 \pm 0.22 \mathrm{~L} \mathrm{mg} \mathrm{C}^{-1} \mathrm{~m}^{-1}\right.$, $n=10, P<0.0001$ ) streams (Fig. 3d). We found a negative 


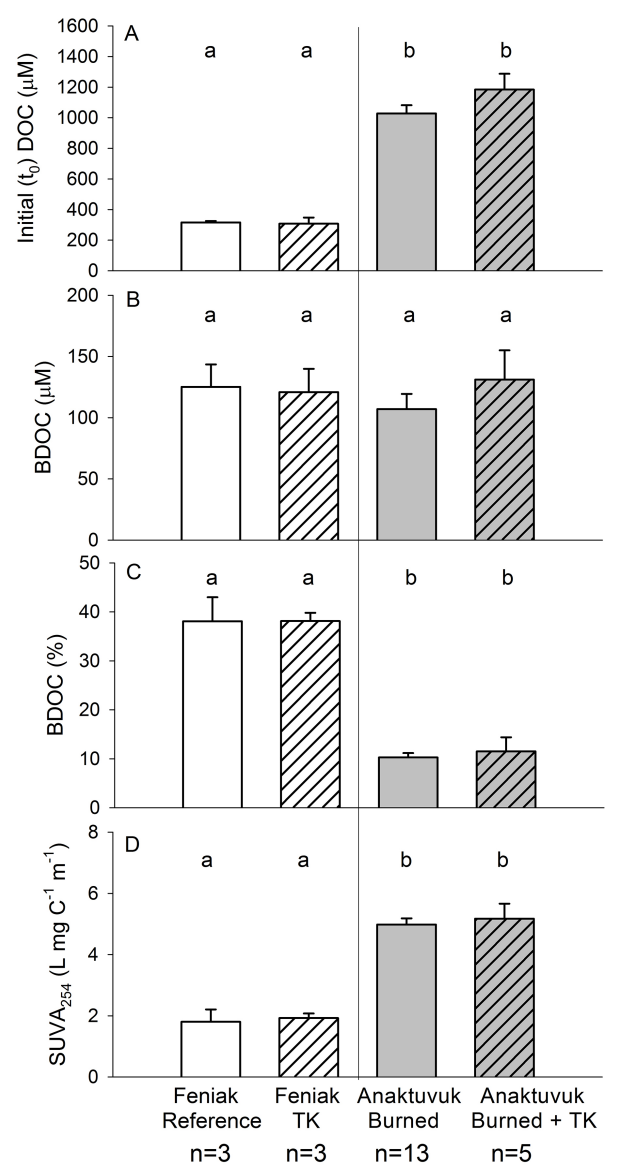

Figure 2. Assessing the impact of thermokarst on stream DOC quantity (a); biodegradability in terms of absolute loss (b) and percent loss (c) after 40 days; and SUVA $_{254}$ (d). Means and standard error are reported. Sample size $(n)$ represents an individual sampling event of stream reach. "Feniak Reference" and "Feniak TK" groups each represent 3 stream reaches sampled upstream and downstream of active thermokarst features one time in the Feniak region. The "Anaktuvuk Burned" group represents 3 stream reaches, one of which was sampled five times and two of which were sampled four times within the fire boundary. The "Anaktuvuk Burned + TK" group represents one stream reach within the fire boundary that contains multiple active layer detachment slide thermokarst within its watershed, sampled five times over the season. ANOVA was used to detect differences for the two comparisons. Similar letters indicate no differences.

exponential relationship between $\mathrm{SUVA}_{254}$ and $\mathrm{BDOC} \%$ (Fig. S2).

\subsection{Background water chemistry}

Most background water chemistry variables differed significantly among regions (Fig. 4). Stream alkalinity was approximately five-fold higher in the Feniak streams $\left(1734 \pm 1167 \mu \mathrm{eq} \mathrm{L}^{-1}, n=40\right)$ compared to alkalinity in Toolik $\left(310 \pm 69 \mu \mathrm{eqL} \mathrm{L}^{-1}, n=74, P<0.0001\right)$ and Anaktuvuk $\left(361 \pm 287 \mu \mathrm{eqL} \mathrm{L}^{-1}, n=168, \quad P<0.0001\right)$ streams.

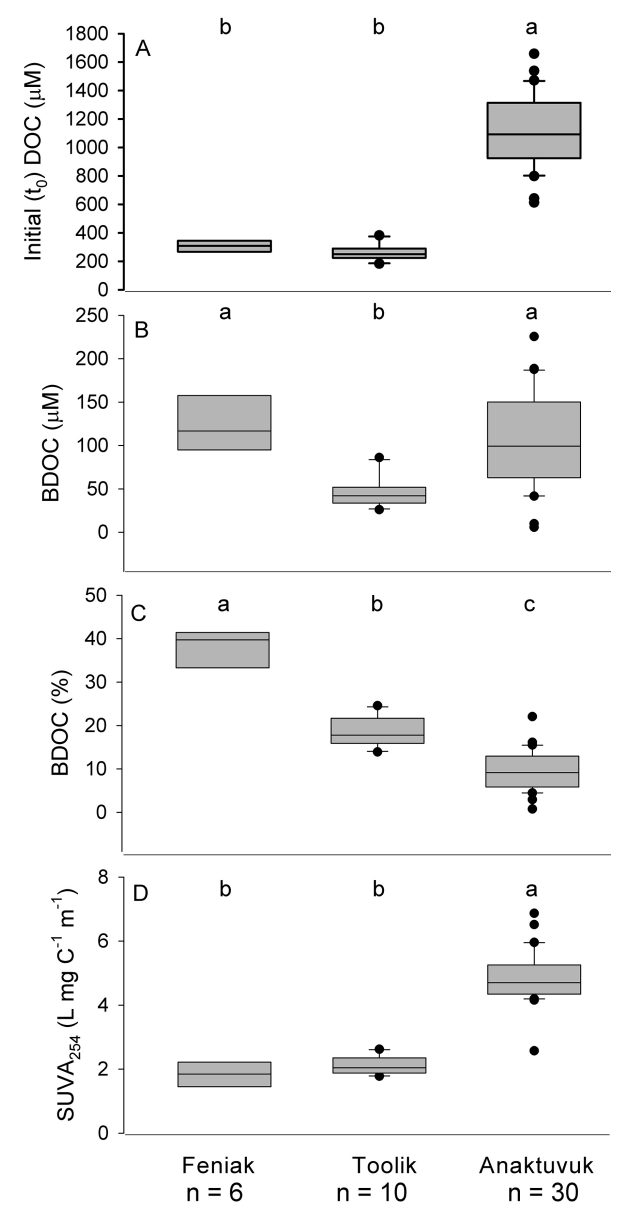

Figure 3. Assessing the impact of region (regardless of treatment) on stream DOC quantity (a); Biodegradability in terms of absolute loss (b) and percent loss (c) after 40 days; and SUVA 254 (d). Box plots represent median, quartiles, minimum, and maximum within 1.5 times the interquartile range (IQR), and outliers beyond 1.5 IQR. Sample size $(n)$ represents a sampling of a stream on a given day. The "Feniak" group represents 6 stream reaches sampled one time in the Feniak region. The "Toolik" group represents 2 stream reaches sampled 5 times over the season. The "Anaktuvuk" group represents 6 burned stream reaches sampled 4-5 times plus the 2 unburned sites sampled once. Different letters represent significant differences between regions, $\alpha=0.05$.

Anaktuvuk streams contained approximately three times the amount of TDN and TDP compared to Feniak and Toolik streams $(P<0.0001)$. Ammonium $\left(\mathrm{NH}_{4}^{+}\right)$concentrations in the Feniak streams were variable, but two of the sites contained particularly high concentrations. Nitrate $\left(\mathrm{NO}_{3}^{-}\right)$was significantly different $(P<0.0001)$ across all three regions with Toolik having the highest concentrations $(5.57 \pm 1.65 \mu \mathrm{M}, n=74)$, followed by Feniak $(3.64 \pm 3.56 \mu \mathrm{M}, n=40)$ and Anaktuvuk $(0.26 \pm 0.81 \mu \mathrm{M}$, $n=168$ ). No significant differences were found across regions for phosphate $\left(\mathrm{PO}_{4}^{3-}\right)$. Mean values for site-specific 
background water chemistry metrics can be found in Table S3.

We compared background water chemistry between the Anaktuvuk reference sites (from the opportunistic sampling of sites 3 and 4 on 06 August 2011) and burned sites using data only from that date (data not shown). We found that $\mathrm{NH}_{4}^{+}$(Reference $0.15 \pm 0.12 \mu \mathrm{M}, n=4$, vs. Burn $0.63 \pm 0.11 \mu \mathrm{M}, n=5, P=0.02$ ), $\mathrm{PO}_{4}^{3-}$ (Reference $0.06 \pm 0.04 \mu \mathrm{M}, n=4$, vs. Burn $0.26 \pm 0.04 \mu \mathrm{M}$, $n=5, P=0.01$ ), and TDP (Reference $0.10 \pm 0.10 \mu \mathrm{M}$, $n=4$, vs. Burn $0.49 \pm 0.06 \mu \mathrm{M}, n=8, P=0.01$ ) were all significantly higher in the burned streams compared to the reference streams on that date. Background DOC was marginally higher (Reference $915 \pm 174 \mu \mathrm{M}, n=4$, vs. Burn mean $1341 \pm 123 \mu \mathrm{M}, n=8, P=0.07$ ) in the burned streams, while $\mathrm{NO}_{3}^{-}$was significantly higher in the reference streams (Reference $3.65 \pm 0.94 \mu \mathrm{M}, n=4$, vs. Burn streams $0.24 \pm 0.67 \mu \mathrm{M}, n=8, P=0.01)$.

\subsection{Seasonal patterns of BDOC}

Biodegradability of DOC did not change significantly over time in five of the eight streams from which repeat measurements were taken (Fig. 5a). The pattern in DOC biodegradability across the season differed among the three alluvial streams. BDOC \% from samples obtained from the Kuparuk River (Site 1) and South River (Site 5) increased (Fig. 5b). In contrast, BDOC \% from samples obtained from Oksrukyuik Creek (Site 2) decreased as the season progressed (Fig. 5c).

\section{Discussion}

Contrary to our hypothesis, we found that streams disturbed by thermokarst and fire did not contain significantly altered labile DOC fractions compared to adjacent reference waters. The quantity, composition and biodegradability of riverine DOC sampled in this study differed primarily by region, likely driven by unique landscape and watershed characteristics (e.g. lithology; soil and vegetation type; elevation; and glacial age). Watershed characteristics influence ecological patterns by controlling the chemistry of soils (Jenny, 1980); plants (Stohlgren et al., 1998); water (Hynes, 1975); and microbial community composition (Larouche et al., 2012). Thus, it is not surprising to observe differences in DOC quantity and character across the three different regions sampled. A circumboreal study across diverse watersheds found that DOC loadings also varied by region (i.e. extent of permafrost and runoff; Tank et al., 2012). The range of BDOC \% from streams and rivers measured in this study $(4-46 \%)$ is similar to other studies of Arctic riverine BDOC $(<10-40 \%$; Wickland et al., 2007; Holmes et al., 2008; Mann et al., 2012).

\subsection{Short-lived effects from fire and thermokarst}

Our study tested for differences in DOC quantity and biodegradability across three geographic regions for headwater stream reaches disturbed by fire and thermokarst. DOC in thermokarst outflow is highly biodegradable (Woods et al., 2011; Cory et al., 2013; Vonk et al., 2013), though biodegradability returns to pre-disturbance levels once features stabilized (Abbott et al., 2014). Two potential explanations for the lack of thermokarst impact in this study are the relatively small portion of the watersheds occupied by thermokarst and the fact that the receiving streams were relatively large (2nd and 3rd order, in the case of Twin 1 and 3 in the Feniak region), diluting highly labile DOC exported from thermokarst at the watershed scale. The two comparisons of the Valley of Thermokarst Reference watershed vs. the Impacted in the burned landscape also did not show an expected impact attributed to the presence of stabilized active layer detachment slides. In this case, the lack of physical and hydrologic connectivity between the slides on the south-facing hillslope and the stream valley bottom, and the rapid stabilization of the features may explain the lack of a watershed-scale influence. Approximately 2-3 years had passed since active layer detachment slide initiation when we sampled for BDOC. Moreover, 2011 was a particularly dry summer season with few storm events resulting in limited hydrologic connectivity between disturbed surfaces and the stream. A study in the High Canadian Arctic also concluded that seasonal solute export from watersheds disturbed by thermokarst (disturbed watershed areas range from 6-46\%) were more sensitive to increased soil temperatures and rainfall events than to the presence of active layer detachments (Lafrenière and Lamoureux, 2013).

Cory et al. (2014) concluded that DOC in thermokarst outflow, with little prior exposure to light is $>40 \%$ more susceptible to microbial conversion to $\mathrm{CO}_{2}$ when exposed to UV light than when kept dark (Cory et al., 2013). Cory et al. (2014) also found that the majority of DOC (70-95\%) transferred from soils through surface waters (e.g. headwater streams, rivers and lakes) in the Arctic simply undergoes photolysis to $\mathrm{CO}_{2}$ (i.e. some combination of photomineralization and partial photo-oxidation), rather than bacterial respiration (i.e. biological mineralization). Therefore, there is strong evidence that highly biodegradable DOC from active thermokarst features may be processed in transit from the hillslope (Abbott et al., 2014), particularly if the flow paths are exposed to light (Cory et al., 2013), which may explain why we did not see significant differences between upstream and downstream thermokarst-impacted reaches in this study. In general, there is conflicting evidence about the effects of thermokarst on surface water biogeochemistry (Lamoureux and Lafrenière, 2009; Lewis et al., 2011; Dugan et al., 2012). In the study of the impact of a gully feature on an Arctic headwater stream, despite the fact that thermokarst outflow had a unique water quality signature from permafrost 
degradation, there was no discernible impact on the receiving stream, likely because thermokarst discharge was small compared to stream discharge and recovery of the thermokarst disturbance was rapid (Larouche et al., 2015). Thus, it is possible that the majority of the labile DOC liberated via thermokarst will not have a strong overall impact on the biogeochemistry of receiving aquatic ecosystems.

The typical post-burn biogeochemical signal that many have found in lower latitude ecosystems may not manifest in burned Arctic watersheds due to the added complexity of permafrost dynamics that also change due to fire. Monitoring and modeling efforts in the terrestrial system of the Anaktuvuk River Fire scar suggest that tundra surface properties (e.g. greenness, albedo, thaw depth) appear to recover rapidly post-fire (Rocha et al., 2012). DOC quantity and biodegradability may have been altered immediately after the tundra burned but our sampling 4 years post-fire may have missed the initial response to fire.

\subsection{Picking an appropriate reference for paired watershed studies}

We originally planned for the Toolik river sites (Kuparuk and Oksrukyuik) to be the reference sites for the burned streams. Had we not opportunistically sampled the two sites north of the burn boundary or the sites in the Feniak region, we may have attributed differences in water chemistry to fire disturbance rather than watershed characteristics. Even though we detected no effect of fire and thermokarst on BDOC, we had a limited sample size and therefore low power in making this statistical conclusion. We conclude that water chemistry differs significantly by region (Fig. 4), regardless of disturbance. However, when we compare the Anaktuvuk reference sites to the east of the burn boundary with the sites within the burned area from a single sampling date on 06 August 2011 (the only date we were able to sample reference sites outside of the burned boundary) we found significant differences in water chemistry (i.e. higher $\mathrm{DOC}, \mathrm{NH}_{4}^{+}, \mathrm{PO}_{4}^{3-}$, TDP and lower $\mathrm{NO}_{3}^{-}$in the burned streams, data not shown). There could also be differences in BDOC metrics between the Anaktuvuk reference and burned streams, but our sample size is too small to detect this difference.

\subsection{Why do DOC pools and biodegradability differ by region?}

Landscape age and associated ecosystem differences may explain the differences in BDOC we observed. The Anaktuvuk landscape is substantially older $(>700 \mathrm{ka})$ than the younger surfaces of Toolik (10-400 ka) and Feniak (50$80 \mathrm{ka}$ ). Older landscapes can have deeper soil organic layers with more decomposed soil organic layers (Hobbie and Gough, 2004), potentially resulting in lower DOC biodegradability in streamwater. Elevation could also play a role with warmer air and soil temperatures accelerating decomposition
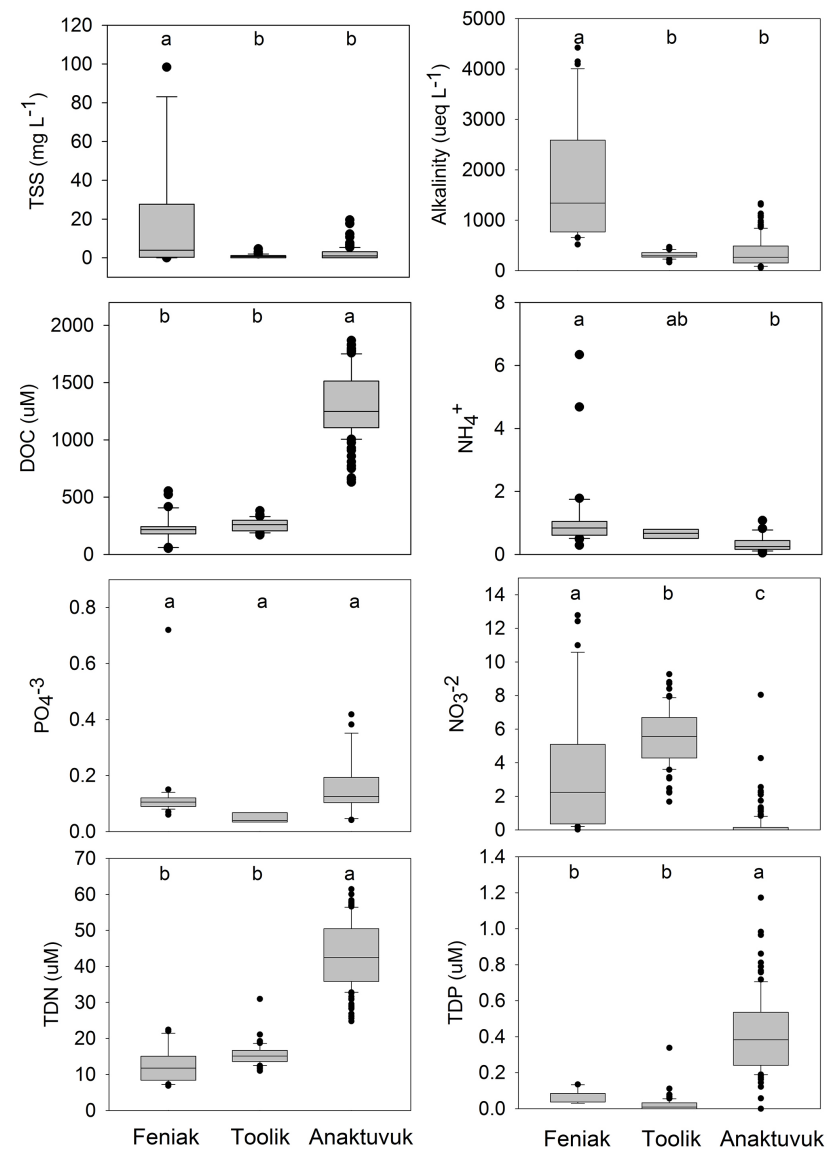

Figure 4. Biogeochemical characteristics of streams within each region (includes all available data, not just from BDOC sampling sites/dates). Box plots represent median, quartiles, minimum and maximum within 1.5 times the interquartile range, and outliers beyond 1.5 IQR. Different letters represent significant differences between regions, $\alpha=0.05$. Sample sizes vary (see text).

in the Anaktuvuk $(285 \pm 17 \mathrm{~m})$ region compared to Feniak $(757 \pm 18 \mathrm{~m})$ and Toolik $(604 \pm 33 \mathrm{~m})$ areas. The older landscape and lower elevation in the Anaktuvuk area may explain the higher concentrations of DOC, TDN and TDP and the lower DOC biodegradability observed in the streams, independent of the impact of fire or thermokarst. Recent ecosystem modeling of nutrient dynamics in the Anaktuvuk burn scar predicted an accumulation of nutrients in soil during the early stages of succession due to sustained or accelerated mineralization of nutrients from organic matter in combination with decreased plant nutrient demand due to sparse plant cover post fire (Yueyang et al., 2015). Abundant nutrients in the soil post fire could be transported to streams, consistent with our observations of high nitrogen and phosphorus in the Anaktuvuk streams.

The three study areas had distinct vegetation communities (Table 1) and the concentration and characteristics of streamwater DOC differ according to its source (McDowell and Likens, 1988). We found that Anaktuvuk stream samples 
contained high DOC concentration of low biodegradability and that the area sampled (i.e. in the southern area of the burn scar) likely receives allochthonous inputs from moist acidic tundra (MAT) communities (Jorgenson et al., 2010). Conversely, Feniak streams, which receive allochthonous inputs from moist non-acidic tundra (MNAT; Jorgenson et al., 2010), contained low DOC concentration of high biodegradability. In general, the rivers in the Toolik area contained low DOC concentration of a relatively recalcitrant form. Thermokarst features draining MNAT have higher BDOC compared to MAT, perhaps due to accelerated decomposition of dissolved organic matter from higher $\mathrm{N}$ availability in acidic tundra before reaching the stream (Abbott et al., 2014). Thus, the MNAT vegetation type in the Feniak area may explain its high BDOC $\%$.

Arctic rivers and streams are generally high in dissolved organic matter and low in inorganic nutrients (Dittmar and Kattner, 2003). Although there is little evidence for nutrient limitation of DOC degradation, background dissolved inorganic $\mathrm{N}$ concentrations were positively correlated with BDOC \% in thermokarst outflow (Abbott et al., 2014). Feniak streams also tend to have higher concentrations of $\mathrm{NH}_{4}^{+}$, potentially alleviating any limits on DOC uptake caused by nitrogen availability. Anaktuvuk streams contain an order of magnitude higher concentrations of DOC, TDN and TDP, compared to Feniak and Toolik streams, potentially explained by the older landscape age and also stream type (i.e. all but one of the stream sites sampled in the Anaktuvuk area were of the beaded type which tend to contain more peat and therefore potentially greater amounts of stored carbon, nitrogen and phosphorus). The morphology of streams and watershed characteristics such as soil type likely play an important role in inorganic nutrient concentrations that may inturn affect DOC biodegradability. However, there is mixed evidence on whether nutrient availability is directly linked to biodegradability of Arctic DOC (Abbott et al., 2014; Holmes et al., 2008). Surface-subsurface connectivity with the hyporheic zone, and rates of nutrient regeneration differ between beaded and alluvial Arctic stream systems (Greenwald et al., 2008).

Another important consideration is DOC adsorption reactions and the role of suspended sediment and exposed mineral soils in permafrost areas disturbed by thermokarst and/or fire. In this study we found some of the streams in the $\mathrm{Fe}$ niak region (those that were impacted by thermokarst) contained high concentrations of total suspended sediment. Feniak streams had lower DOC concentration, but DOC was more biodegradable. This pattern is consistent with observations of low DOC concentration following thermokarst and fire in lakes, likely due to adsorption of DOC to exposed mineral soil and suspended mineral soil particles (Kokelj et al., 2005). The input of suspended mineral soil from thermokarst can result in greater transparency in the water column compared to undisturbed lakes (Kokelj et al., 2009) due to adsorption of organic material by mineral sediment
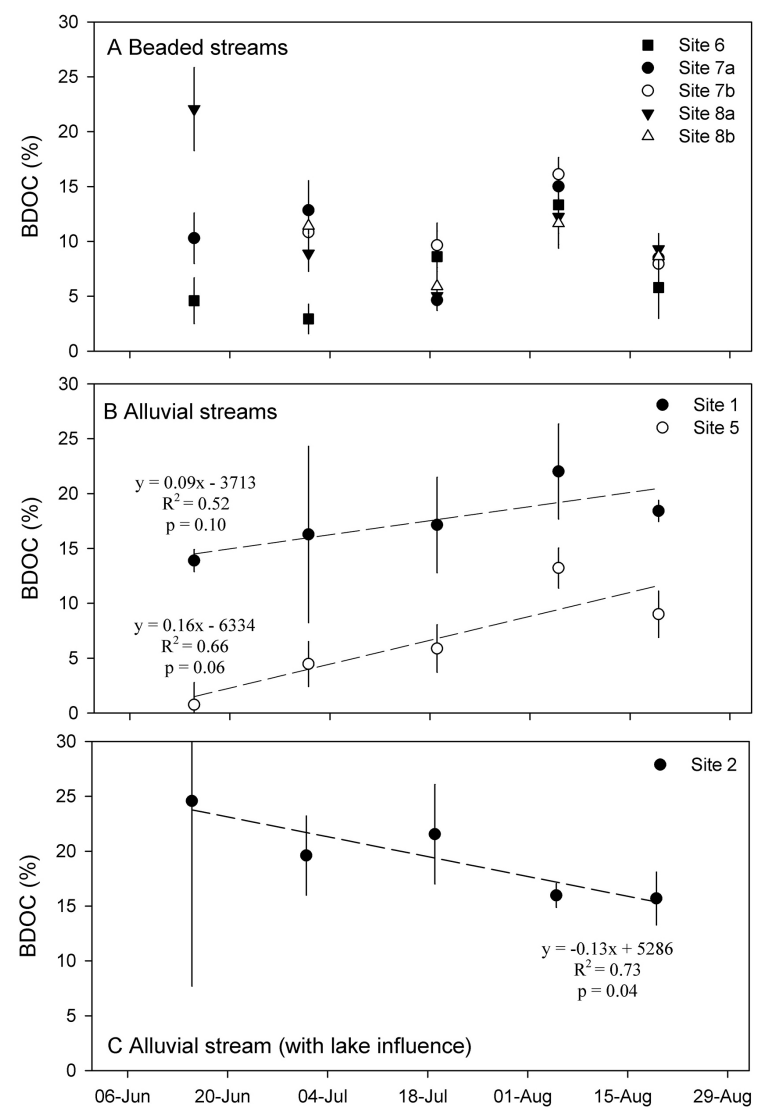

Figure 5. Seasonal trends in BDOC (\%): (a) beaded stream sites no significant trends; (b) alluvial sites without any lake influence significantly increasing trends; (c) alluvial site with lake influence upstream - significantly decreasing trend. Each symbol and associated error bars represent the mean BDOC $(\%)$ and the standard error of the four field replicates.

from slumps that adsorbs DOC and then settles to the lake bottom (Thompson et al., 2008).

\subsection{Seasonality of BDOC}

Contrary to several studies showing highest BDOC during snowmelt, followed by a decrease through the growing season (Holmes et al., 2008; Spencer et al., 2008; Mann et al., 2012; Raymond et al., 2007), we found variable seasonal patterns of BDOC. The majority of these studies are in larger, arctic river systems whereas our study sampled 1st and 2nd order headwater streams. Stream morphology may also play a role since beaded streams are made up of ice-rich polygons that may contain older forms of DOC and are typically colder compared to alluvial systems (Brosten et al., 2006). Thermoerosion gullies, a common upland thermokarst type, often form from the thaw of ice-rich polygons and the outflow from gullies contained the least biodegradable DOC compared to other feature types, although still elevated compared to reference waters (Abbott et al., 2014). Thus, although polygonal 
areas are susceptible to thaw via gully formation or beaded stream formation, it is possible that the ice wedges contain low BDOC \%. We observed an increase in BDOC \% in the Kuparuk River (Site 1) and South River (Site 5), both of which are alluvial systems without any lake influence upstream of the river network (Fig. 5b), whereas we observed a decreasing trend in BDOC \% in Oksrukyuik Creek, an alluvial system with a series of lakes upstream of our sampling point (Fig. 5c). In the alluvial streams without lakes, it is likely that after the pulse of labile terrestrial DOC during the freshet (which our study did not sample), tundra plant and in-stream algal productivity increases as the growing season progresses and in-turn increases stream DOC biodegradability as sources shift from allochthonous to autochthonous. We suggest that the lake effect in the Oksrukyuik Creek watershed serves as a reservoir for a pulse of highly labile, aquatic-derived BDOC in the beginning of the growing season, following the flush from the terrestrial ecosystem during the spring freshet. The BDOC in general from the alluvial stream with the lake influence is more labile (BDOC \% range 15.7-24.6) compared to the alluvial systems without lakes (BDOC \% range 0.75-13.9) as it leaks from the rich lake environment down the watershed, likely seeding the stream with rich material from the lake across the season.

\section{Conclusions}

Although active thermokarst outflow contains highly biodegradable DOC (Woods et al., 2011; Cory et al., 2013; Vonk et al., 2013; Abbott et al., 2014) and dissolved organic matter biodegradability from boreal soil leachate is lower from burned than unburned soils (Olefeldt et al., 2013), we found no significant effect of fire or thermokarst in the streams we sampled. Our study indicates strong variation of stream water chemistry and DOC quantity, biodegradability, and aromaticity based on landscape characteristics. Although elevated concentrations and export of sediment and nutrients from thermokarst have been documented (Bowden et al., 2008; Kokelj et al., 2009; Lamoureux and Lafrenière, 2009; Lamoureux and Lafrenière, 2014), the impact on hydrologic export depends largely on the magnitude and type of thermokarst disturbance, the time from initial disturbance to stabilization, and the hydrologic connectivity between the feature and downslope aquatic ecosystems (Lewis et al., 2011; Shirokova et al., 2013; Thienpont et al., 2013). Although thermokarst gullies and active layer detachment slides are the dominant thermokarst types in the area we sampled (e.g. $\sim 80 \%$ of all the thermokarst in the vicinity of the Toolik Field Station; Krieger, 2012), their relatively short-lived active export period prior to stabilization may not significantly alter landscape-scale biogeochemical cycling. Conflicting reports of the effects of permafrost disturbance on BDOC suggest that substantial uncertainty remains about the vulnerability of aquatic ecosystems as the permafrost re- gion warms. Given the complexities and interactions of the controlling biogeochemical variables on Arctic-dissolved organic matter, monitoring thermokarst and fire impacts at both the site and watershed scales, as well as the consideration of landscape characteristics could address this disconnect.

\section{The Supplement related to this article is available online at doi:10.5194/bg-12-4221-2015-supplement.}

Author contributions. J. R. Larouche and B. W. Abbott designed the experiment, collected and analyzed samples and collaborated closely on the manuscript written by J. R. Larouche. W. B. Bowden and J. B. Jones advised on the design of the experiment, assisted with the data analysis, and edited the final manuscript.

Acknowledgements. We thank the many individuals and organizations that assisted with this study. S. Godsey, A. Olsson, L. Koenig, and P. Tobin assisted with laboratory and field work. R. Cory and G. Kling provided technical assistance and advice with DOC analysis. A. Balser and J. Stuckey provided assistance with landscape classification and watershed characteristics and J. Noguera with the Toolik Field Station GIS and Remote Sensing Facility provided the map for this manuscript. We thank the staff of Toolik Field Station and of $\mathrm{CH} 2 \mathrm{M}$ Hill Polar Services logistical services and support. Staff from the Arctic Network of the National Park Service and Bureau of Land Management facilitated research permits. This work was supported by the National Science Foundation's Arctic Systems Science Program under grant number ARC-0806394. Any opinions, findings, and conclusions or recommendations expressed in this material are those of the authors and do not necessarily reflect the views of the National Science Foundation.

Edited by: W. F. Vincent

\section{References}

Abbott, B. W., Larouche, J. R., Jones, J. B., Bowden, W. B., and Balser, A. W.: Elevated dissolved organic carbon biodegradability from thawing and collapsing permafrost, J. Geophys. Res.Biogeo., 2014JG002678, doi:10.1002/2014jg002678, 2014.

Balcarczyk, K., Jones Jr., J., Jaffé, R., and Maie, N.: Stream dissolved organic matter bioavailability and composition in watersheds underlain with discontinuous permafrost, Biogeochemistry, 94, 255-270, doi:10.1007/s10533-009-9324-x, 2009.

Balser, A. W., Jones, J. B., and Gens, R.: Timing of retrogressive thaw slump initiation in the Noatak Basin, northwest Alaska, USA, J. Geophys. Res.-Earth, 119, 2013JF002889, doi:10.1002/2013jf002889, 2014.

Bayley, S. E., Schindler, D. W., Beaty, K. G., Parker, B. R., and Stainton, M. P.: Effects of Multiple Fires on Nutrient Yields from Streams Draining Boreal Forest and Fen Watersheds: Nitrogen and Phosphorus, Can. J. Fish. Aquat. Sci., 49, 584-596, doi:10.1139/f92-068, 1992a. 
Bayley, S. E., Schindler, D. W., Parker, B. R., Stainton, M. P., and Beaty, K. G.: Effects of forest fire and drought on acidity of a base-poor boreal forest stream: similarities between climatic warming and acidic precipitation, Biogeochemistry, 17, 191204, doi:10.1007/bf00004041, 1992b.

Belshe, E. F., Schuur, E. A. G., and Grosse, G.: Quantification of upland thermokarst features with high resolution remote sensing, Environ. Res. Lett., 8, 1-10, 2013.

Betts, E. F. and Jones, J. B.: Impact of Wildfire on Stream Nutrient Chemistry and Ecosystem Metabolism in Boreal Forest Catchments of Interior Alaska, Arct. Antarct. Alp. Res., 41, 407-417, doi:10.1657/1938-4246-41.4.407, 2009.

Bowden, W. B., Gooseff, M. N., Balser, A., Green, A., Peterson, B. J., and Bradford, J.: Sediment and nutrient delivery from thermokarst features in the foothills of the North Slope, Alaska: Potential impacts on headwater stream ecosystems, J. Geophys. Res.-Biogeo., 113, G02026, doi:10.1029/2007jg000470, 2008.

Brosten, T. R., Bradford, J. H., McNamara, J. P., Zarnetske, J. P., Gooseff, M. N., and Bowden, W. B.: Profiles of temporal thaw depths beneath two arctic stream types using ground-penetrating radar, Permafrost Periglac., 17, 341-355, doi:10.1002/ppp.566, 2006.

Burn, C. R.: The response (1958-1997) of permafrost and nearsurface ground temperatures to forest fire, Takhini River valley, southern Yukon Territory, Can. J. Earth Sci., 35, 184-199, doi:10.1139/e97-105, 1998

Chorover, J., Vitousek, P., Everson, D., Esperanza, A., and Turner, D.: Solution chemistry profiles of mixed-conifer forests before and after fire, Biogeochemistry, 26, 115-144, doi:10.1007/bf02182882, 1994.

Cory, R. M., Crump, B. C., Dobkowski, J. A., and Kling, G. W.: Surface exposure to sunlight stimulates $\mathrm{CO}_{2}$ release from permafrost soil carbon in the Arctic, P. Natl. Acad. Sci., 110, 34293434, doi:10.1073/pnas.1214104110, 2013.

Cory, R. M., Ward, C. P., Crump, B. C., and Kling, G. W.: Sunlight controls water column processing of carbon in arctic fresh waters, Science, 345, 925-928, doi:10.1126/science.1253119, 2014.

Dittmar, T. and Kattner, G.: The biogeochemistry of the river and shelf ecosystem of the Arctic Ocean: a review, Mar. Chem., 83, 103-120, doi:10.1016/S0304-4203(03)00105-1, 2003.

Dugan, H. A., Lamoureux, S. F., Lewis, T., and Lafrenière, M. J.: The Impact of Permafrost Disturbances and Sediment Loading on the Limnological Characteristics of Two High Arctic Lakes, Permafrost Periglac., 23, 119-126, doi:10.1002/ppp.1735, 2012.

Fellman, J. B., Hood, E., Edwards, R. T., and D'Amore, D. V.: Changes in the concentration, biodegradability, and fluorescent properties of dissolved organic matter during stormflows in coastal temperate watersheds, J. Geophys. Res.-Biogeo., 114, G01021, doi:10.1029/2008jg000790, 2009.

Frey, K. E. and McClelland, J. W.: Impacts of permafrost degradation on arctic river biogeochemistry, Hydrol. Process., 23, 169182, doi:10.1002/hyp.7196, 2009.

Gooseff, M. N., Balser, A., Bowden, W. B., and Jones, J. B.: Effects of Hillslope Thermokarst in Northern Alaska, Eos Trans. AGU, 90, 29-30, doi:10.1029/2009eo040001, 2009.

Greenwald, M. J., Bowden, W. B., Gooseff, M. N., Zarnetske, J. P., McNamara, J. P., Bradford, J. H., and Brosten, T. R.: Hyporheic exchange and water chemistry of two arctic tundra streams of contrasting geomorphology, J. Geophys. Res., 113, G02029, doi:10.1029/2007JG000549, 2008.

Hamilton, T. D.: Surficial geology of the Dalton Highway (Itkillik-Sagavanirktok rivers) area, southern Arctic foothills, Alaska, Alaska Division of Geological \& Geophysical Surveys Professional Report 121, 32 pp., 1 sheet, scale 1:63, 360, doi:10.14509/7191, 2003.

Hamilton, T. D.: Guide to surficial geology and river-bluff exposures, Noatak National Preserve, northwestern Alaska, 116 pp., 2009.

Hamilton, T. D. and Labay, K. A.: Surficial Geologic Map of the Gates of the Arctic National Park and Preserve, Alaska, U.S. Geological Survey (in cooperation with U.S. National Park Service), Scientific Investigations Map 3125, 1 : 300000 scale, and accompanying report, 19 pp., 2011.

Harms, T., Abbott, B., and Jones, J.: Thermo-erosion gullies increase nitrogen available for hydrologic export, Biogeochemistry, 117, 299-311, doi:10.1007/s10533-013-9862-0, 2014.

Higuera, P. E., Chipman, M. L., Barnes, J. L., Urban, M. A., and Hu, F. S.: Variability of tundra fire regimes in Arctic Alaska: millennial-scale patterns and ecological implications, Ecol. Appl., 21, 3211-3226, doi:10.1890/11-0387.1, 2011.

Hobbie, S. E. and Gough, L.: Litter decomposition in moist acidic and non-acidic tundra with different glacial histories, Oecologia, 140, 113-124, 2004.

Holmes, R., McClelland, J., Peterson, B., Tank, S., Bulygina, E., Eglinton, T., Gordeev, V., Gurtovaya, T., Raymond, P., Repeta, D., Staples, R., Striegl, R., Zhulidov, A., and Zimov, S.: Seasonal and Annual Fluxes of Nutrients and Organic Matter from Large Rivers to the Arctic Ocean and Surrounding Seas, Estuar. Coasts, 35, 369-382, doi:10.1007/s12237-011-9386-6, 2012.

Holmes, R. M., Peterson, B. J., Gordeev, V. V., Zhulidov, A. V., Meybeck, M., Lammers, R. B., and Vörösmarty, C. J.: Flux of nutrients from Russian rivers to the Arctic Ocean: Can we establish a baseline against which to judge future changes?, Water Resour. Res., 36, 2309-2320, doi:10.1029/2000wr900099, 2000.

Holmes, R. M., McClelland, J. W., Raymond, P. A., Frazer, B. B., Peterson, B. J., and Stieglitz, M.: Lability of DOC transported by Alaskan rivers to the arctic ocean, Geophys. Res. Lett., 35, L03402, doi:10.1029/2007g1032837, 2008.

Hynes, H. B. N.: The stream and its valley, 1-15, 1975.

Jenny, H.: The Soil Resource Origin and Behavior, Ecological Studies, 37, Springer-Verlag, New York, 377 pp., 1980.

Jones, B. M., Kolden, C., Jandt, R., Abatzoglu, J., Urban, F., and Arp, C.: Fire behavior, weather, and burn severity of the 2007 Anaktuvuk River tundra fire, North Slope, Alaska, Arct. Antarct. Alp. Res., 41, 309-316, 2009.

Jorgenson, M., Yoshikawa, K., Kaveskiy, M., Shur, Y., Romanovsky, V., Marchenko, S., Grosse, G., Brown, J., and Jones, B.: Permafrost characteristics of Alaska, Proceedings of the 9th International Conference on Permafrost, Fairbanks, Alaska, 121122, 2008.

Jorgenson, M. T., Roth, J. E., Miller, P. F., Macander, M. J., Duffy, M. S., Wells, A. F., Frost, G. V., and Pullman, E. R.: An ecological land survey and landcover map of the Arctic Network, Natural Resource Technical Report NPS/ARCN/NRTR-2009/270, edited, National Park Service, Fort Collins, Colorado, 2010. 
Jorgenson, M. T., Shur, Y. L., and Pullman, E. R.: Abrupt increase in permafrost degradation in Arctic Alaska, Geophys. Res. Lett., 33, L02503, doi:10.1029/2005g1024960, 2006.

Kokelj, S. V. and Jorgenson, M. T.: Advances in Thermokarst Research, Permafrost Periglac., 24, 108-119, doi:10.1002/ppp.1779, 2013.

Kokelj, S. V., Jenkins, R. E., Milburn, D., Burn, C. R., and Snow, N.: The influence of thermokarst disturbance on the water quality of small upland lakes, Mackenzie Delta Region, Northwest Territories, Canada, Permafrost Periglac., 16, 343-353, doi:10.1002/ppp.536, 2005.

Kokelj, S. V., Zajdlik, B., and Thompson, M. S.: The Impacts of Thawing Permafrost on the Chemistry of Lakes across the Subarctic Boreal-Tundra Transition, Mackenzie Delta Region, Canada, Permafrost Periglac., 20, 185-199, doi:10.1002/ppp.641, 2009.

Kokelj, S. V., Lacelle, D., Lantz, T. C., Tunnicliffe, J., Malone, L., Clark, I. D., and Chin, K. S.: Thawing of massive ground ice in mega slumps drives increases in stream sediment and solute flux across a range of watershed scales, J. Geophys. Res.-Earth, 118, 681-692, doi:10.1002/jgrf.20063, 2013.

Krieger, K. C.: The topographic form and evolustion of thermal erosion features: A first analysis using airborne and ground-based LiDAR in Arctic Alaska, MS, Department of Geosciences, Idaho State University, 98 pp., 2012.

Lafrenière, M. J. and Lamoureux, S. F.: Thermal Perturbation and Rainfall Runoff have Greater Impact on Seasonal Solute Loads than Physical Disturbance of the Active Layer, Permafrost Periglac., 24, 241-251, doi:10.1002/ppp.1784, 2013.

Lamoureux, S. and Lafrenière, M.: Fluvial Impact of Extensive Active Layer Detachments, Cape Bounty, Melville Island, Canada, Arct. Antarct. Alp. Res., 41, 59-68, doi:10.1657/1938-4246(08030)[lamoureux]2.0.co;2, 2009.

Lamoureux, S. F. and Lafreniere, M. J.: Seasonal fluxes and age of particulate organic carbon exported from Arctic catchments impacted by localized permafrost slope disturbances, Environ. Res. Lett., 9, 1-10, doi:10.1088/1748-9326/9/4/045002, 2014.

Lane, D. M.: Tukey's Honestly Significant Difference (HSD). Encyclopedia of Research Design, SAGE Publications, Inc, SAGE Publications, Inc., Thousand Oaks, CA, 1566-1571, 2010.

Larouche, J. R.: Thermokarst and Wildfire: Effects of Disturbances Related to Climate Change on the Ecological Characteristics and Functions of Arctic Headwater Streams, PhD, Rubenstein School of Environment and Natural Resources, University of Vermont, 220 pp., 2015.

Larouche, J. R., Bowden, W. B., Giordano, R., Flinn, M. B., and Crump, B. C.: Microbial Biogeography of Arctic Streams: Exploring Influences of Lithology and Habitat, Front. Microb., 3, 309, doi:10.3389/fmicb.2012.00309, 2012.

Levene, H.: Contributions to Probability and Statistics: Essays in Honor of Harold Hotelling, I, edited by: Olkin, I., Stanford University Press, 278-292, 1960.

Lewis, T., Lafrenière, M. J., and Lamoureux, S. F.: Hydrochemical and sedimentary responses of paired High Arctic watersheds to unusual climate and permafrost dis 26, 2003-2018, doi:10.1002/hyp.8335, 2012.

Mack, M. C., Bret-Harte, M. S., Hollingsworth, T. N., Jandt, R. R., Schuur, E. A. G., Shaver, G. R., and Verbyla, D. L.: Carbon loss from an unprecedented Arctic tundra wildfire, Nature, 475, 489492, 2011.

Malone, L., Lacelle, D., Kokelj, S., and Clark, I. D.: Impacts of hillslope thaw slumps on the geochemistry of permafrost catchments (Stony Creek watershed, NWT, Canada), Chem. Geol., 356, 3849, doi:10.1016/j.chemgeo.2013.07.010, 2013.

Mann, P. J., Davydova, A., Zimov, N., Spencer, R. G. M., Davydov, S., Bulygina, E., Zimov, S., and Holmes, R. M.: Controls on the composition and lability of dissolved organic matter in Siberia's Kolyma River basin, J. Geophys. Res.-Biogeo., 117, G01028, doi:10.1029/2011jg001798, 2012.

McClelland, J. W., Stieglitz, M., Pan, F., Holmes, R. M., and Peterson, B. J.: Recent changes in nitrate and dissolved organic carbon export from the upper Kuparuk River, North Slope, Alaska, J. Geophys. Res.-Biogeo., 112, G04s60, doi:10.1029/2006jg000371, 2007.

McDowell, W. H. and Likens, G. E.: Origin, Composition, and Flux of Dissolved Organic Carbon in the Hubbard Brook Valley, Ecol. Monogr., 58, 177-195, doi:10.2307/2937024, 1988.

McDowell, W. H., Zsolnay, A., Aitkenhead-Peterson, J. A., Gregorich, E. G., Jones, D. L., Jödemann, D., Kalbitz, K., Marschner, B., and Schwesig, D.: A comparison of methods to determine the biodegradable dissolved organic carbon from different terrestrial sources, Soil Biol. Biochem., 38, 1933-1942, doi:10.1016/j.soilbio.2005.12.018, 2006.

McGuire, A. D., Anderson, L. G., Christensen, T. R., Dallimore, S., Guo, L., Hayes, D. J., Heimann, M., Lorenson, T. D., Macdonald, R. W., and Roulet, N.: Sensitivity of the carbon cycle in the Arctic to climate change, Ecol. Monogr., 79, 523-555, doi:10.1890/08-2025.1, 2009.

Nolan, M.: Distribution of a Star3i DEM of the Kuparuk River watershed. Joint Office for Scientific Support, Boulder, Colorado, 2003.

O’Donnell, J. A., Aiken, G. R., Walvoord, M. A., and Butler, K. D.: Dissolved organic matter composition of winter flow in the Yukon River basin: Implications of permafrost thaw and increased groundwater discharge, Global Biogeochem. Cy., 26, GB0E06, doi:10.1029/2012gb004341, 2012.

Olefeldt, D., Turetsky, M., and Blodau, C.: Altered Composition and Microbial versus UV-Mediated Degradation of Dissolved Organic Matter in Boreal Soils Following Wildfire, Ecosystems, 16, 1396-1412, doi:10.1007/s10021-013-9691-y, 2013.

Osterkamp, T. E. and Romanovsky, V. E.: Evidence for warming and thawing of discontinuous permafrost in Alaska, Permafrost Periglac., 10, 17-37, doi:10.1002/(sici)10991530(199901/03)10:1<17::aid-ppp303>3.0.co;2-4, 1999.

Petrone, K. C., Hinzman, L. D., Shibata, H., Jones, J. B., and Boone, R. D.: The influence of fire and permafrost on sub-arctic stream chemistry during storms, Hydrol. Process., 21, 423-434, doi:10.1002/hyp.6247, 2007.

Randerson, J. T., Liu, H., Flanner, M. G., Chambers, S. D., Jin, Y., Hess, P. G., Pfister, G., Mack, M. C., Treseder, K. K., Welp, L. R., Chapin, F. S., Harden, J. W., Goulden, M. L., Lyons, E., Neff, J. C., Schuur, E. A. G., and Zender, C. S.: The Impact of Boreal Forest Fire on Climate Warming, Science, 314, 1130-1132, doi:10.1126/science.1132075, 2006.

Raymond, P. A., McClelland, J. W., Holmes, R. M., Zhulidov, A. V., Mull, K., P eterson, B. J., Striegl, R. G., Aiken, G. R., and Gurtovaya, T. Y.: Flux and age of dissolved organic car- 
bon exported to the Arctic Ocean: A carbon isotopic study of the five largest arctic rivers, Global Biogeochem. Cy., 21, GB4011, doi:10.1029/2007gb002934, 2007.

Rocha, A. V., Loranty, M. M., Higuera, P. E., Mack, M. C., Feng Sheng, H., Jones, B.M., Breen, A. L., Rastetter, E. B., Goetz, S. J., and Shaver, G. R..: The footprint of Alaskan tundra fires during the past half-century: implications for surface properties and radiative forcing, Environ. Res. Lett., 7, 1-8, 2012.

Romanovsky, V., Burgess, M., Smith, S., Yoshikawa, K., and Brown, J.: Permafrost temperature records: Indicators of climate change, Eos Trans. AGU, 83, 589-594, doi:10.1029/2002eo000402, 2002.

Romanovsky, V., Oberman, N., Drozdov, D., Malkova, G., Kholodov, A., and Marchenko, S.: Permafrost in State of the Climate in 2010, B. Am. Meteorol. Soc., 92, 152-153, 2011.

Schindler, D., Curtis, P. J., Bayley, S., Parker, B., Beaty, K., and Stainton, M.: Climate-induced changes in the dissolved organic carbon budgets of boreal lakes, Biogeochemistry, 36, 9-28, doi:10.1023/a:1005792014547, 1997.

Shiklomanov, N. I., Streletskiy, D. A., Nelson, F. E., Hollister, R. D., Romanovsky, V. E., Tweedie, C. E., Bockheim, J. G., and Brown, J.: Decadal variations of active-layer thickness in moisture-controlled landscapes, Barrow, Alaska, J. Geophys. Res.-Biogeo., 115, G00I04, doi:10.1029/2009jg001248, 2010.

Shirokova, L. S., Pokrovsky, O. S., Kirpotin, S. N., Desmukh, C., Pokrovsky, B. G., Audry, S., and Viers, J.: Biogeochemistry of organic carbon, $\mathrm{CO}_{2}, \mathrm{CH}_{4}$, and trace elements in thermokarst water bodies in discontinuous permafrost zones of Western Siberia, Biogeochemistry, 113, 573-593, doi:10.1007/s10533012-9790-4, 2013.

Spencer, R. G. M., Aiken, G. R., Wickland, K. P., Striegl, R. G., and Hernes, P. J.: Seasonal and spatial variability in dissolved organic matter quantity and composition from the Yukon River basin, Alaska, Global Biogeochem. Cy., 22, GB4002, doi:10.1029/2008gb003231, 2008 .

Stohlgren, T., Bachand, R., Onami, Y., and Binkley, D.: Speciesenvironment relationships and vegetation patterns: effects of spatial scale and tree life-stage, Plant Ecol., 135, 215-228, doi:10.1023/a:1009788326991, 1998.

Striegl, R. G., Aiken, G. R., Dornblaser, M. M., Raymond, P. A., and Wickland, K. P.: A decrease in discharge-normalized DOC export by the Yukon River during summer through autumn, Geophys. Res. Lett., 32, L21413, doi:10.1029/2005g1024413, 2005.

Tank, S. E., Frey, K. E., Striegl, R. G., Raymond, P. A., Holmes, R. M., McClelland, J. W., and Peterson, B. J.: Landscapelevel controls on dissolved carbon flux from diverse catchments of the circumboreal, Global Biogeochem. Cy., 26, GB0E02, doi:10.1029/2012gb004299, 2012.

Thienpont, J. R., RÜHland, K. M., Pisaric, M. F. J., Kokelj, S. V., Kimpe, L. E., Blais, J. M., and Smol, J. P.: Biological responses to permafrost thaw slumping in Canadian Arctic lakes, Freshwater Biol., 58, 337-353, doi:10.1111/fwb.12061, 2013.
Thompson, M. S., Kokelj, S. V., Wrona, F. J., and Prowse, T. D.: The impact of sediments derived from thawing permafrost on tundra lake water chemistry: An experimental approach, in: Proceedings of the Ninth International Conference on Permafrost, edited by: Kane, D. L. and Hinkel, K. M., Fairbanks Alaska, Institute of Northern Engineering, University of Alaska Fairbanks, 2, 1763 1768, 2008.

Toolik Environmental Data Center Team: Meterological monitoring program at Toolik, Alaska, Toolik Field Station, Institute of Arctic Biology, University of Alaska Fairbanks, Fairbanks Alaska, 2011.

Viereck, L. A., Dyrness, C. T., Batten, A. R., and Wenzlick, K. J.: The Alaska Vegetation Classification, edited by: U.S.D.A. Forest Service, 278 pp., Gen. Tech. Rep. PNW-GTR-286, Portland, Oregon, 1992.

Vonk, J. E., Mann, P. J., Davydov, S., Davydova, A., Spencer, R. G. M., Schade, J., Sobczak, W. V., Zimov, N., Zimov, S., Bulygina, E., Eglinton, T. I., and Holmes, R. M.: High biolability of ancient permafrost carbon upon thaw, Geophys. Res. Lett., 40, 2689 2693, doi:10.1002/grl.50348, 2013.

Wang, X., Ma, H., Li, R., Song, Z., and Wu, J.: Seasonal fluxes and source variation of organic carbon transported by two major Chinese Rivers: The Yellow River and Changjiang (Yangtze) River, Global Biogeochem. Cy., 26, GB2025, doi:10.1029/2011gb004130, 2012.

Weishaar, J. L., Aiken, G. R., Bergamaschi, B. A., Fram, M. S., Fujii, R., and Mopper, K.: Evaluation of specific ultraviolet absorbance as an indicator of the chemical composition and reactivity of dissolved organic carbon, Environ. Sci. Technol., 37, 47024708, doi:10.1021/es030360x, 2003.

Wickland, K., Neff, J., and Aiken, G.: Dissolved Organic Carbon in Alaskan Boreal Forest: Sources, Chemical Characteristics, and Biodegradability, Ecosystems, 10, 1323-1340, doi:10.1007/s10021-007-9101-4, 2007.

Woods, G. C., Simpson, M. J., Pautler, B. G., Lamoureux, S. F., Lafrenière, M. J., and Simpson, A. J.: Evidence for the enhanced lability of dissolved organic matter following permafrost slope disturbance in the Canadian High Arctic, Geochim. Cosmochim. Ac., 75, 7226-7241, doi:10.1016/j.gca.2011.08.013, 2011.

Western Regional Climate Center: available at: http://www.wrcc. dri.edu (last access: September 2014), 2011.

Yoshikawa, K., Bolton, W. R., Romanovsky, V. E., Fukuda, M., and Hinzman, L. D.: Impacts of wildfire on the permafrost in the boreal forests of Interior Alaska, J. Geophys. Res.-Atmos., 107, 8148, doi:10.1029/2001jd000438, 2002.

Yueyang, J., Rastetter, E. B., Rocha, A., Pearce, A. R., Kwiatkowski, B. L., and Shaver, G.: Carbon-Nutrient interactions during the early recovery of tundra after fire, Ecol. Appl., doi:10.1890/14-1921.1, in press, 2015. 